\title{
A physicist joins the race for Congress
}

\section{Colin Macilwain}

There are only three scientists in Congress, but Rush Holt, former assistant director of the Princeton Plasma Physics Laboratory, believes he can become the fourth. He comfortably won the primary to become the Democrat nominee in New Jersey's twelfth district.

[FREEHOLD, NEW JERSEY] "People are surprised to find a physicist who is adept at this," says Rush Holt, the former assistant director of the Princeton Plasma Physics Laboratory, as he pauses between a quick canvassing tour of a retirement community and a sparsely attended, open-air press conference on a wet, muggy morning in New Jersey.

Holt left the laboratory, the largest fusion research facility in the United States, last October to run for Congress in New Jersey's twelfth district.

The evidence of Holt's adeptness is his unexpectedly comfortable victory in a primary election in June, when he easily defeated a wealthy rival, Carl Meyer, to become the Democratic nominee for this well-heeled strip of suburban New Jersey.

Now he stands, as his literature puts its, as "teacher, scientist, Democrat" for one of the handful of the 435 congressional districts that political analysts believe may actually change hands in November.

If Holt wins, he would be the fourth $\mathrm{PhD}$ scientist in Congress, joining physicist Vernon Ehlers (Republican, Michigan), chemist John Olver (Democrat, Massachusetts) and physiologist Roscoe Bartlett (Republican, Maryland). But, as a one-time arms-control official at the State Department who spent much of the past ten years trying to secure support for fusion research in Washington, he would be the first to arrive at Capitol Hill with extensive science policy experience.

Holt is standing against Republican Michael Pappas, who won the seat in 1996 with only 49 per cent of the vote. This narrow margin of victory, and the fact that Pappas is a 'freshman' member who has only had two years to accumulate goodwill in the district, puts it near the top of the target list of Republican seats that Democrats hope to win in November. They need 11 gains to regain control of the House of Representatives.

Holt's campaign seeks to paint Pappas as an "extremist" who supports policies on issues such as abortion and the environment that are out of line with the district's moderate electorate. Pappas has been walking a fine line to protect himself from this charge. The League of Conservation Voters, for example, gives his environmental voting record the lowest ranking of any New Jersey congress- man, but the highest ranking of any Republican freshman in the entire House.

Holt concedes that Pappas is not the easiest of targets. "He keeps his head down, but his voting record shouts 'extremist." Pappas failed to respond to calls asking him to defend his record.

If elected, Holt does not plan to seek any radical changes in the way Congress allocates money for research. He also says that any attempt to centralize responsibility for science policy, for example in a Department of Science, would be a "disaster". But he adds that he will work to get Congress to respond to global warming and biodiversity conservation, science-driven issues that he claims Pappas has ignored.

At this early stage, the top priority of both candidates is raising money. Holt says he will need \$1 million, but expects Pappas to raise at least $\$ 1.25$ million. It was reported in the district that the Democratic Party in Washington wanted Meyer to win the primary, as he had \$1 million of his own to spend, whereas they doubted Holt's ability to raise the cash needed to make the race competitive.

Holt confounded them, raising $\$ 311,000$ by the end of June. Much of it has come from scientists, including former colleagues, science policy professionals in Washington and scientists from across the country, including half-a-dozen Nobel laureates.

"These are not traditional donors, but [they] feel deeply about the issues," he says. The traditional contributors — including political action committees run by environmental groups and labour unions - can be expected to pour money into the later stages of the campaign if the seat looks winnable.

The district meanders from the rural county of Hunterdon down through Princeton almost to the Jersey shore, and has no real centre or dominant newspaper.

Television advertising would be inefficient and prohibitively expensive in a district sandwiched between Philadelphia and New York, so the best way to reach voters will be through grass-roots campaigning. Holt was enjoying this last week, greeting voters mostly Jewish retirees from New York City, who will draw their last breath before voting Republican - at the Covered Bridge retirement community.

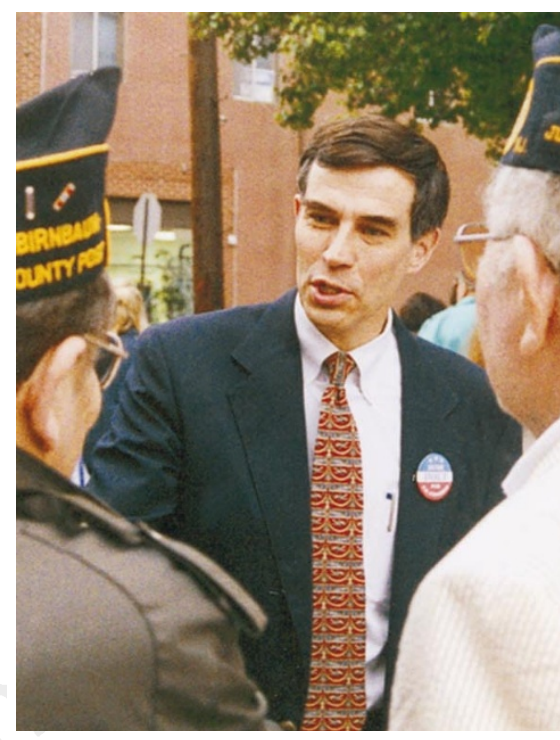

Holt: if elected, he would push Congress to act on global warming and biodiversity conservation.

"He has a good chance of winning," says Harry Sayen, a columnist for the Trenton Times, who says that moderate Republicans in the Princeton area will desert Pappas. "Republicans voted for him in 1996 without realizing what kind of Republican he was."

Although Holt promotes himself as a scientist, Sayen suggests he keeps quiet about it, even in a district where as many as two thirds of voters had a college education. "You shouldn't push academia too hard, or people think of you as an egghead," he says.

That advice is echoed by Vernon Ehlers, who says he decided not to emphasize his scientific credentials when he first ran for Congress in 1993. But being a scientist brought him a decisive break in that campaign.

In a televised debate, two of his rivals for the Republican nomination were boasting that their backgrounds, as a lawyer and a businessman respectively, would make them effective on Capitol Hill. "I just said that I had checked and there were 181 lawyers and 135 businesspeople in the Congress," Ehlers recalls. "But if I were elected, it would double the number of scientists." He won the primary and the election.

George Brown (Democrat, California), the senior Democrat on the House Science Committee, feels that more scientists and engineers are needed in the legislature. "There's no reward structure for the scientist who goes into politics," says the veteran Congressman. "The pay's not great and they lose their status in their own community."

That doesn't bother Holt, who believes he can win in November even without a national swing to the Democrats. A poll for his campaign says only 30 per cent of district voters want to re-elect Pappas. "The polling data is very good, and I'm finding good vibes in the district. Those who know me best are working hard for me, and that's not always true for politicians." 